\title{
Sağlık Hizmetlerinde Podolojinin Gelişimi ve Eğitimine Genel Bir Bakış
}

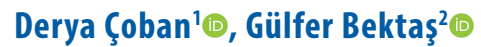

${ }^{1}$ Acıbadem Mehmet Ali Aydınlar Üniversitesi, Podoloji Programı, İstanbul, Türkiye

${ }^{2}$ Acıbadem Mehmet Ali Aydınlar Üniversitesi, Sağlık Yönetimi, İstanbul, Türkiye

Derya Çoban

Gülfer Bektaş, Doç. Dr.
Iletişim:

Doç. Dr. Gülfer Bektaş

Acıbadem Mehmet Ali Aydınlar Üniversitesi, Sağlık Yönetimi, İstanbul, Türkiye

Tel: +902165004192

E-Posta: gulfer.bektas@acibadem.edu.tr
Gönderilme Tarihi : 12 Mart 2018

Revizyon Tarihi : : 08 Mayıs 2018

Kabul Tarihi : : 22 Mayıs 2018
ÖZET

Podoloji, podos- (ayak) ve -loji (bilim) sözcüklerinden oluşan ve dünyada tarihi çok eskilere dayanmasına rağmen, Türkiye'de çok yeni olan bir bilim dalıdır. Türkiye'deki gelişimi 2008 yılında Podoloji Derneği'nin kurulmasını takip eden çalışmalarla ve podologluğun meslek kanununun 26.04.2011 tarihinde yayınlanmasıyla başlamıştır. Podoloji, vücudumuzda organ fonksiyon bozukluklarının alt ekstremitede sinir, damar, eklem, cilt üzerine olan olumsuz etkilerini tanımlayan ve verdiği hasarı önleyici tedbirlerle azaltmaya çalışan bir sağlık mesleğidir. Türkiye'deki mesleki gelişimi çok yeni olmakla birlikte dünyada gelişimi eskilere dayanmaktadır.

Bu çalışmadaki amaç, konjenital, edinsel ya da travmaya bağlı olarak gelişen ayak hastalıklarına yönelik birtakım primer / önleyici / koruyucu ve tedavi edici sağlık hizmetleri veren podoloğun eğitimini, podoloji alanına giren uygulamaları ve podologların mesleki gelişimini inceleyerek, Türkiye'de podolojinin sağlık hizmet sunumundaki yerini ve önemini vurgulamaktır.

Anahtar sözcükler: Podoloji, podolog, ayak sağlı̆ı, podiatri

\section{A GENERAL VIEW OF EDUCATION AND DEVELOPMENT OF PODOLOGY IN HEALTHCARE SERVICES}

\section{ABSTRACT}

Podology is a term that is formed by the Greek words podos- (foot) and -logy (science), and it refers to a field of science that has long been known in the world, despite its very recent history in Turkey. The development of the field in Turkey started with the studies following the foundation of Podology Association in 2008, which led to the definition of the profession in Turkish Law and Regulations on 26 April 2011. Podology is mainly a health profession which aims to define the negative impacts of the organ function disorders on the nerves, veins, joints and skin of the lower extremities and to reduce the harm inflicted on these body parts by using preventive measures. The aim of this article is to emphasize the (value or significance) and importance of podology in healthcare services in Turkey, by analyzing the applications in podology in addition to the professional development and education of the podologist who provides primary / preventive / protective healthcare services for patients of congenital, acquired, or trauma-induced foot problems.

Key words: Podology, podologist, foot health, podiatry

odos- (ayak) ve -loji (bilim) eklerinin birleşmesiyle türemiş bir terim olan podoloji, ayakta oluşan hastalıkları tanımlayan ve ayağın bakımı ve sağlığı ile ilgili çalışmaları kapsayan bir bilim dalıdır. Tıp terimleri sözlüğünde podoloji, "ayağın fizyolojisini, anatomisini, mekaniğini ve patolojisini anlamaya yönelik çalışma ve uygulamaları içeren; ayaktaki hastalıkların teşhis ve tedavisini, klinik ayak problemlerinin engellenmesini ya da hafifletilmesini amaçlayan bir sağlık hizmeti alanıdır" olarak tanımlanmaktadır (1). 
Podoloji her ne kadar tıbbi ve multidisipliner bir çalışma alanını içerse de, Türkiye'deki sürece bakıldığında henüz geniş kitlelere ulaşabilmiş değildir. Bu nedenle de ayak sağlığı ve uygulamaları ile ilgili yürütülmüş akademik çalışmalar az sayıda medikal dergi ve kitaplarla sınırlı kalmıştır. Genel akademik araştırmalara bakıldığında, Türkiye'de podoloji alanına ait öncül bilimsel çaIışmalar konusunda da yetersizlikler görülmektedir. Oysa Türkiye'de de, tüm dünyada olduğu gibi sağlık alanında değişik branşlardan oluşan bir ekip tarafından verilen sağlık hizmeti ile hastaların değişen ihtiyaçların giderilmesi hedeflenmektedir. Hem ülkemizde, hem dünyada hastalıklardan korunma birinci önceliktir ve bu nedenle de sağlık politikalarında hastalıkları önleyici tedbirler ön planda yer almaktadır. Örneğin, değişen intiyaçlar arasında yaşlanmakta olan nüfusta, gittikçe artan ölçüde kardiovasküler sorunlar, diyabet, kas ve kemik yapısında bozulmalar gibi problemler sayılabilir. Bu durum, sağlık hizmetlerine yönelik artan bir talep oluşturmaktadır (2). Bu açıdan değerlendirildiğinde podolojinin, Türkiye'de yeni gelişmekte olan bir sağlık mesleği olarak önemi son dönemlerde gittikçe artmaktadır. Bu noktada, dünyada podolojinin çeşitli ülkelerdeki tarihsel gelişiminin ve ülkeler bazında verilen eğitimlerin mevcut durumunun incelenmesi, podolojinin ülkemizde akademik ve uygulamaya yönelik bir alan olarak bilinirliğini artırmaya yardımcı olacaktır.

\section{Podolojinin tarihsel gelişimi ve Ülke örnekleri}

Alman podolog Klaus Grünewald'in Theorie der medizinischen Fußbehandlung (2002) adlı eserinde, ayak bakımının tıbbi tarihçesinin daha ilk çağlardan başlayarak şifacılıkla yakın ilişsiler içerisinde olduğu belirtilmektedir. Bu kitaptaki ifadelere bakılarak, "en eski şifa kitaplarından biri olan ve M.Ö. 1500 yıl önceye ait olan Papyros Ebers isimli şifa kitabında, 'aeb' kelimesi geçmektedir"(3). Bu da kitabı çeviren H. Joachim'e göre "nasır" anlamına gelmektedir. Kitapta temel olarak nasır tedavisinde uygulanabilecek yöntemler anlatılmıştır (3). Grünewald'in eserinde ayrıca şu bilgiler yer almaktadır: "Tıbbın babası olarak bilinen Hipokrat (M.Ö. 460-377) da ayak bakımıyla yakından ilgilenmiştir. Sırasıyla, Gaius Plinius Secundus (M.S. 23-79), Marcellus Empiricus (M.S. 379) ve Aetius (M.S. 550)'un da podoloji ile ilgili çalışmalar yaptıkları bilinmektedir" (3).

Yine Grünewald'e göre, "podoloji, 12. yüzyıldan itibaren yeni bir meslek dalı olarak gelişmeye başlamıştır. Almanya'da bu mesleğe 'Bader' ismi verilmiştir. Bu meslek dalı, basit cerrahi işlemlere yönelik uygulamalar, tıraş ve hamamcılıkla birlikte yürütülmekteydi. Fakat aynı zamanda nasırları ve siğilleri iyileştirmek de bu iş koluna aitti" (3). Hekimlik mesleği, o dönemde de bir üniversite mezuniyetine bağlı olduğundan, "Baderler," hekimler için zorunlu olan kurallardan bağımsız bir biçimde "halkın şifacıları" olarak görev yapmaktaydılar. Grünewald'e göre, 'Baderler' hekim ve eczacılardan bağımsız bir cerrahlar topluluğu kurmuşlardır. Bu topluluğun mensupları, nasırlara basit cerrahi müdahaleler ve siğillerin yok edilmesi gibi çalışmaların yanı sıra diş çekimini de üstlenebiliyorlardı.

"Bader" mesleği 17. yüzyılda Adrian Brouwer (16051638)'in Die Dorfbaderstube (köy 'Bader'hanesi) isimli eserinde (Resim 1) ve Davis Teniers d. J. (1610-1690)'in Die Baderstube ('Bader'hane) isimli eserinde( Resim 2) incelikleriyle resmedilmiştir. Her iki tablonun ana konusu o günlerde gerçekleştirilen ayak bakımıdır $(4,5)$.

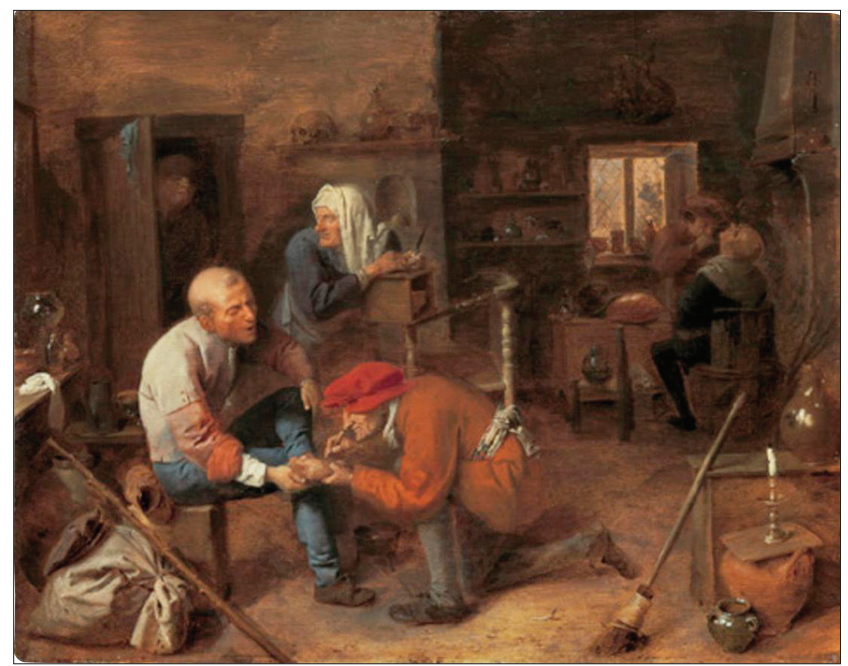

Resim 1: Adrian Brouwer, Die Dorfbaderstube (4)

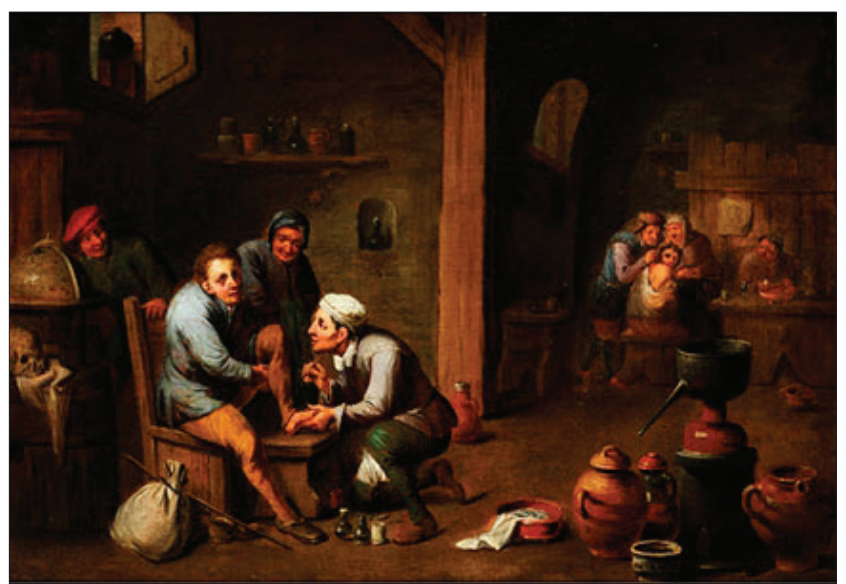

Resim 2: David Tenier, Die Baderstube (5) 
"Bader" mesleğini takiben, Almanya'daki ayak bakımının tarihçesi, İngiltere ve Fransa'daki ayak bakımıyla doğru orantılı gelişmiştir. Grünewald'in eserine göre, "ayak bakımı, özellikle 18. yüzyılda mesleklerini Almanya ve Avusturya'da icra etmeleri yasaklanan ve bu nedenle göç etmek zorunda kalan Yahudilerce yaygınlaştırılmıştır. İngiltere ve Fransa'daki bu göçmenlerin içlerinden çok başarılı ve iyi eğitimli meslektaşlar ortaya çıkmıştır. Bu zanaatkârların hem 'diş hekimi' hem de 'nasır ameliyatçısı' olarak görev almaları, 18. yüzyıla kadar devam etmiştir" (3).

Grünewald'in değindiği en önemli ayak uzmanları arasında, aslen Almanya'nın Durlach kasabasından göç etmiş olan Abraham Durlacher (1757-1845) de bulunmaktadır. Buna göre, Durlacher "ayak bakımı konusunda meşhur olmuş bu göçmenlerden biridir. Kendisi önce sosyetik bir kaplıca olan Bath şehrinde mesleğini icra etmiştir, fakat sonra Londra'ya taşınmıştır. Tek oğlu olan (1792-1864) Lewis, üç kitap yazmıştır. Bu kitaplardan temel eser sayılabilecek olanı $A$ Treatise of Corns (Nasırların Tedavisi) isimli kitabıdır. Bu eser, 1845 yılında Amerika, Philadelphia'da yayınlanmıştır. Lewis Durlacher mesleğini en üst düzeyde icra etmesi nedeniyle hem Kraliyet ailesinin hem de Londra'da bu işi gerçekleştiren hekimlerin saygınlığını kazanmıştı"(3).

Fransa'da da ayak bakımı açısından benzer gelişmeler yaşanmıştır. 1762 yılında ilk defa bir pedikürcünün kitabı yayınlanmıştır. Eser, Rousselot tarafından yazılmıştır ve üç ciltten oluşmaktadır. Yine Fransa'da Nicolas-Laurent Laforest, 1782 yılında çok saygı gören kitabında kendisinin kullandığı aletlerin resimlerini yayınlamıştır. Grünewald'e göre, Laforest'in "yayınlamış olduğu on bir adet bistürün şekli günümüzdeki aletlere benzemektedir. O zamanlar kullanılan tırnak keskisi bugün kullanılanlarla neredeyse aynıdır. Her iki yazar da o dönem Napolyon tarafından verilen 'Chirurgien Pedicure de LL. MMe. Imperials et Royales' (Kraliyet Hanedanı ve İmparatorluk Ayak Cerrahi Uzmanı ve Eğiticisi) unvanına layık görülmüşlerdir. Rousselot ve Laforest'in kitapları Fransa'da podolojnin gelişimi için çığır açıcı nitelikte eserlerdir"(3).

Ayak bakım ürünlerinin gelişimi açısından önemli bir adım ise Avusturya'da atılmıştır. Grünewald'in tarihçesinde, bu adım şöyle anlatılmaktadır: "Avusturyalı Sigmund Wolffsohn (1767-1852), 1835 yılında ayaktaki baskıyı hafifletici ürünü için patent almıştır. Bu ürünün malzemesi (Feuerschwamm) bir mantarın özütünden elde edilmekteydi. Elde edilen özüte plastik sürülüp ipek kumaşla kaplanmıştı. Ancak 1900 yılından itibaren ayaktaki baskıyı hafifletmek için Wolffsohn'un ürünü yerine keçe halkalar kullanılmaya başlanmıştır" (3).
1946 ile 1948 yılları arasında, ayak bakımında iki farklı ilgi alanı oluşmaya başlamış ve her biri farklı yönlere doğru gelişmiştir. Grünewald'in kategorizasyonuna göre, "bir grup, 'Bader' mesleğinin tıbbi yöne doğru ilerlemesini seçmiştir. Diğer grup ise podoloji mesleğinin bir zanaat olarak gelişmesi için yol almıştır. Zanaata doğru yönelen grup, 1950'li yıllarda İktisadi Bilimler Enstitüsü'nün ve Alman Ortopedistler Birliği'nin bir raporu ile dağıtılmıştır. Bu rapor sebebiyle, bu meslek, zanaatlar ve zanaata benzer kollar odasına alınmamıştır. Ancak daha sonra, Almanya'da bulunan tıbbi ayak bakımı ile ilgili meslek dernekleri 1955 yılında bir meslek birliği olarak birleşmiştir. Bu meslek birliğinin katkısıyla podoloji, o zamandan bu yana tanınmış ve saygın bir meslek olarak görülmekte ve tıbbi destek mesleği olarak varlığını sürdürmektedir" (3).

Birleşik Krallık'ta podoloji mesleği diğer Avrupa ülkelerine göre daha farklı biçimlerde icra edilmektedir. Burada genel olarak podologlara "chiropodist" (şiropodist) ismi verilmektedir ve bu kişiler, "cilt cerrahisi, batan tırnakların çıkarılması gibi ayakta cilt ve tırnaklarda oluşan lezyonlardan kaynaklanan semptomların giderilmesi için basit önlemler sunmakta, yaşlıların ve diyabetik hastaların ayak bakımlarında önemli rol oynamaktadırlar" (6). İngiltere'deki ilk podoloji eseri tıpkı Abraham Durlacher gibi Almanya'dan göç eden, ancak Edinburgh, İskoçya'ya yerleşen göçmenlerden biri olan ve ayakta cerrahi uygulamaları üstlenen Heyman Lion tarafından 1802 yılında kaleme alınmış, Lion bu kitapta kendi kullandığı makas, bistüri ve cımbız gibi aletlerin resimlerine yer vermiştir (3). Lion'dan daha da önce ise, 1785 yılında David Low tarafından kaleme alınan "Chiropodologia, or a Scientific Enquiry into the Causes of Corns, Warts, Onions, and Other Painful or Offensive Cutaneous Excrescences" adlı kitap, şiropodi sözcüğünün ilk kullanıldığı eserdir (6). Bu noktada, şiropodi ve podiatri sözcüklerinin podoloji ile ilgisine ve farklılıklarına da değinilmesi gerekmektedir.

Dagnall'e göre, şiropodi sözcüğünün olası kökeni, Yunanca "el" anlamına gelen kheir ve ayak anlamına gelen podos kelimelerinin birleşimi olabilir. Bir başka olasılık da "çatlamış ayak" anlamına gelen Yunanca kheiropodes sözcüğünden uyarlanmış olmasıdır (6). Podiatri terimi ise Amerika Birleşik Devletleri'nde ortaya çıkmıştır ve "ayak doktoru" anlamına gelir. 1918'de ilk kez Felix Von Defele tarafından podiatrist terimi kullanılmıştır (7). Bununla birlikte, 1958 yılında mesleğin adı resmen şiropodiden podiatriye dönüştürülmüştür. Podiatri eğitimine başvuranlar, yedi podiatri kolejinden birinde dört yıllık eğitime kabul edilmeden önce üç yıllık kolej öğrenimi almıştır; birçok eyalet, çalışma lisansı vermeden önce bir veya iki yıl ihtisasın da tamamlanmasını istemektedir (8). 
Terimin İngilizce konuşulmayan Avrupa ülkelerindeki genel karşılığı ise podolojidir. Bunun nedeni ise dünyada bilinen ilk ve en geniş çaplı podoloji derneğinin 1947 yılında Fransızca konuşulan üçülkenin önderliğinde, Fransa, Belçika ve İsviçre'nin kuruculukları altında oluşmasıdır (9). Bu derneğin kuruluştaki ilk adı Fédération Internationale des Podologues'dur (Uluslararası Podologlar Federasyonu). Bu federasyon, günümüzde kısaca FIP-IFP adı altında çalışmalarını sürdürmekte, her yıl düzenledikleri kongrelerle ve üye ülkelerin her birinde gerçekleştirilen organizasyonlarla podolojinin dünyadaki gelişimine katkıda bulunmaktadır. FIP-IFP'in mevcut üyeleri Avusturya, Danimarka, Almanya, Finlandiya, İtalya, Hollanda, Norveç, İspanya, İsveç, Kanada, Birleşik Krallık ve ABD'dir (9).

Günümüzde pek çok ülke, podolojiyi meslek kanunlarıyla tanımlamış durumdadır. Örneğin, ayak bakım uygulamaları için en kapsamlı düzenlemeleri içeren kanunlardan biri, Almanya'da 2 Ocak 2002 tarihinde çıkan ve profesyonel unvanı "podolog" olarak tanımlayan meslek kanunudur. Bu kanuna göre, Almanya'da sadece resmi bir izin belgesi sahibi olan kişiler bu işin profesyonel unvanını kullanabilir. "Podiatrist" veya "tıbbi pedikürcü / podolog" gibi unvanlar yasa dışı olarak kullanılırsa, bu durum yasal olarak suç teşkil eder ve kişi podolog meslek kanunu uyarınca cezalandırılır (10). Buna göre, verilen eğitimler de yine kanunca belirlenmiş yönetmeliklere uygun olarak yürütülmektedir. Almanya'da podolog kanunun yürürlüğe girmesinden önce, podolog iş ve işlemlerini ilgili derneklerden veya kurslardan aldığı sertifikalarla yapan uzmanlara 2002-2006 arasında geçiş dönemi tanınarak ek bir sınavda başarılı olmak kaydıyla tıbbi unvanlarını "podolog" olarak kullanma ve pratikte de mesleklerini icra etmeyi sürdürme izni verilmiştir. Yine Almanya'daki podolog kanununa benzer şekilde, İspanya'da da podologların aldıkları üniversite eğitimi sonucunda mesleği icra etme biçimleri, İspanyol ve Avrupa Birliği kanunları uyarınca düzenlenmiştir. Örneğin, buradaki kanunlara göre, Valencia Üniversitesi, Hemşirelik ve Şiropodi Fakültesi'nin verdiği dört yıllık lisans eğitimini tamamlayan podologlar, podiatri kliniklerinde, polikliniklerde, hastane ya da spor merkezlerinde çalışabilir, üniversitelerin podiatri ve podoloji bölümlerinde, bilimsel kuruluşlarda ve yine podolojik çalışmaları kapsamına alan derneklerde öğretim elemanı olarak görev yapabilmektedirler (11). Ülkelerdeki mesleki eğitim süreçlerinin, mesleğin kanunca tanımlanmasıyla yakından ilişkili olduğu görülmektedir. Bu nedenle podoloji eğitimi veren çeşitli ülkelerdeki mevcut durumlara ilişkin örnekler verilmesi yararlı olacaktır.

\section{Podoloji eğitiminde mevcut durum: Ülke örnekleri}

Almanya'da, yukarıda verilen bilgilere ek olarak, podoloji eğitimi şu biçimde yürütülmektedir: Devlet onaylı ayak bakımı/podoloji okullarından alınan tam zamanlı iki yıllık ya da yarı zamanlı üç yıllık eğitim ile buradan mezun olanlar hukuken korunmuş isim hakkını elde etmektedirler. 2012 yılında ilk kez bir üniversitede lisans derecesi olarak podolog unvanı veren bir bölüm kurulmuştur. Üç yıllık bir eğitim süresinden sonra, Bachelor of Science of Podology diploması veren becla için Berlin'de bir okul açılmıştır. Bu alandaki profesyonellerin "eğitim ve temsillerinin düzenlenmesi Alman Podiatri Birliği tarafından yürütülmektedir" (10). Almanya'daki podoloji eğitiminin içeriğinde, "temel fizik bilgisi, kimya, anatomi, genel ve özel patoloji, farmakoloji, hijyen ve mikrobiyoloji, ilk yardım ve bandaj teknikleri, önlem ve rehabilitasyon, podolojik bakımın teorik temelleri, genel podolojik tedavi önlemleri ve podolojide fiziksel terapi araçları" gibi dersler bulunmaktadır (12).

İspanya'da eğitime bakıldığında, podoloji eğitimi "podiatri" adı altında verilmekte, ancak bölümün mezunları "podolog" unvanını elde etmektedirler. Bu dört yıllık tam zamanlı eğitimi almadan önce, öğrencilerin altyapı olarak biyoloji, kimya, matematik ve fizik gibi temel bilimlere aşina olmaları beklenmektedir. Eğitimin üçüncü ve dördüncü yıllarında öğrenciler teorik bilgilerini içselleştirmeleri ve gelecekteki mesleklerinde uygulama deneyimi kazanmaları amacıyla stajlara yönlendirilmektedirler. Bu stajlar "bütüncül klinik praktikumu" denilen modülün bir parçasıdır. Buradaki eğitimde öğrenciler podiatrik cerrahi, ortopodiatri, ortotik, fiziksel podiatri, biyomekanik, şiropodi ve radyodiagnoz gibi dersler almaktadırlar (11).

İsviçre'deki durum incelendiğinde Almanya'ya ve İspanya'ya göre daha farklı yasal gereklilikler bulunduğu görülmektedir. Burada podoloji eğitimi alan kişiler üç yıllık tam zamanlı bir eğitimden sonra Federal Yetkinlik Sertifikası ile bu eğitimi tamamlarlar. Çoğu kantondaki serbest meslek için bir ek diploma eğitimi gereklidir ve bu diploma yüksek teknik okullardan alınmaktadır. Bu eğitimde yüksek riskli hastaların tedavisi özel ağırlık kazanmıştır. Eğitim, Almanca konuşulan bölgelerde üç yıl sürmekte ve toplam 3600 çalışma saati içermektedir. Eğitimin temeli, federal olarak onaylanmış çerçeve bir müfredattır. Tıbbi ayak bakımı, çoğu kantonda sağlık yönergelerince düzenlenmiştir. Mesleği icra etmek için podologlar, ilgili kantonun sağlık otoritesinden profesyonel bir lisans uygulama izini almak zorundadırlar $(12,10)$. 
Ingiltere'deki eğitim, tam zamanlı modüler bir sistem olması bakımından İspanya'dakine benzerdir. Lisans, yüksek lisans ve doktora seviyelerinde eğitim almak mümkündür. Kuram ve uygulama dersleri birbirine entegre olarak geliştirilmiştir ve "öğrencilerin değerlendirme, tanı ve tedavide klinik becerilerini geliştirmelerine, hastalardaki normal ve patolojik süreçler üzerine edindikleri bilgileri artırmalarına" olanak tanımaktadır. New College Durham ve Teesside Üniversitesi'nin ortak yürüttüğü podoloji eğitim programI, "Bachelor of Podiatry" (podiatri lisans derecesi) vermekte ve dersler, İnternet üzerinden sunulan materyalle de desteklenmektedir. Burada tamamlanması gereken üç modül bulunmaktadır. 1. modül, klinik uygulama, insan fizyolojisi, dermatoloji, fonksiyonel anatomi ve araştırma derslerinden oluşmaktadır. 2. modül, klinik uygulama ve araştırmaya ek olarak podiatride ilaçlar, lokal anestezi, kaskemik patolojisi derslerini içermekte, modül 3 ise klinik uygulamanın ve araştırmanın son aşaması ile birlikte, tırnak cerrahisi, farmakoloji, uygulamalı podiatri ve biyomekanik derslerini içermektedir (12).

Polonya'daki üç yıllık tam zamanlı eğitim sonucunda mezunlar "Bachelor of medicine, methodology and cosmetology with specialisation in podology" (Podoloji uzmanlık alanı ile tıp, metodoloji ve kozmetoloji lisans derecesi) alırlar. Buradaki eğitimin ideal podoloji eğitimi olduğunu söylemek mümkündür. Öğrenciler, "psikolojiye giriş, sosyal iletişim becerileri, pazarlama hizmetleri ve reklam" gibi genel derslerin yanı sıra, diğer ülkelerdeki "fizyoterapi ya da farmakoloji" gibi alan bilgisi dersleriyle birlikte, alanın derinlemesine uzmanlığını kazandıracak olan "plastik cerrahi, bitkisel tıp tedavileri, toksikoloji, immünoloji, kozmetik bilgisi, diyetoloji ve aroma terapisi" gibi çok çeşitli dersler de almaktadırlar (12).

İtalya'da ve Malta'da eğitimler yine tam zamanlıdır ancak, ilkinde üç yıllık, ikincisinde dört yıllık bir eğitim söz konusudur. Malta'da mezunlar Podiatri lisans diploması alırken, İtalya'daki lisans derecesinin sonucunda verilen unvan podologdur. Eğitimler birbirine benzemekle birlikte, Malta'da "tıp etiği, iletişim, podoloji bilimine giriş, psikoloji, data analizi, istatistik gibi genel derslerin ardından anatomi, patoloji, fizyoloji, biyomekanik, dermatoloji, hematoloji, endokrinoloji, anestezi, romatoloji ve diyabetoloji" gibi dersler verilmektedir. İtalya'da ise, "fizyoloji, cilt hastalıkları, enflamatuar ve metabolik hastalıklar, kaskemik rehabilitasyonu, farmakoloji ve kimya, cerrahi, tıbbi görüntüleme, nöroloji ile genel tıp ve terapileri" dersleri sağlanmaktadır (12).
Ülkemizde ise, mesleğin gelişimi ve tanınırlığı çok yeni olduğundan, mevcut durum diğer ülkelere kıyasla henüz arzu edilen düzeyde değildir.

\section{Podolojinin bir meslek olarak Türkiye'deki mevcut durumu}

Türkiye'de podolojinin bir meslek olarak tanınabilmesi için ilk adım 2008 yılında, Podoloji Derneği'nin kurulması ile atılmıştır. Bu dernek, ülkemizde podoloji alanına yönelik ilk çalışmaları başlatan organizasyondur. Derneğin asıl amacı, podolojinin bir meslek olarak tüm dünyada olduğu gibi Türkiye'de de üniversite düzeyinde bir eğitime sahip olmasını sağlamaktır. Bunun yanı sıra uzman podologlara mesleki istihdam sağlanması ile ülkemizin ekonomik ve sosyal anlamda ilerlemesine katkıda bulunmayı hedefleyen dernek, ayrıca bilimsel eğitimle yetişecek donanımlı podologların sayesinde, ülkemiz insanlarına bu hizmetten maksimum fayda sağlamayı amaçlamaktadır (13).

2008 yılında, Podoloji Derneği ve işKUR ortaklığıyla yapılan çalışma sonucunda, meslek kodu 2269.03 ile podiatrist ve podoloğun Türk meslek terimleri sözlüğünde tanımı yapılmıştır. Yine bu dernek tarafından 2008-2009 döneminde hazırlanan dosya ile meslek standardının hazırlanması ve eğitiminin oluşturulması için Çalışma ve Sosyal Güvenlik Bakanlığı'na bağlı olan Mesleki Yeterlilik Kurumu'na müracaatta bulunulmuştur. Benzer bir dosya aynı tarihlerde Sağlık Bakanlığı'na da verilmiştir. Sağlık Bakanlığı́nın Mesleki Yeterlilik Kurumu'yla yaptığı; "sağlık meslekleriyle ilgili çalışmayı Sağlık Bakanlığı yürütür," şeklindeki protokolün sonucu olarak, hazırlanmış olan dosya Sağlık Bakanlığı tarafından devralınmıştır. Bakanlığın Avrupa yasaları uyum çerçevesinde Türkiye'de eğitimi bulunan ama kanunu olmayan mesleklerle ilgili yaptığı çalışmaya Podoloji / Podolog da dahil edilmiştir.

9 Haziran 2010 tarihinde, Sağlık Bakanlığı́na bağlı, eski adı Tedavi Hizmetleri Genel Müdürlüğü olan, Sağlık Eğitim Genel Müdürlüğü Podoloji Derneği'ne bir davet mektubu göndererek bir çağrıda bulunmuştur. Bu mektupta, podoloji üzerine şu sözler söylenmektedir: "Ülkemizde bireylerin ve toplum sağlığının korunması, geliştirilmesi ve sağlık hizmetlerinin etkili sunumunda sağlık meslek mensuplarının almış oldukları eğitimler doğrultusunda görev, yetki ve sorumluluklarına ait mevzuatın bütünlük içinde yeniden düzenlenmesi intiyaç haline gelmiştir. Bu bağlamda Bakanlığımız düzenleyici işlemlerinin yeniden yapılandırılması amacıyla; (Sağlık Meslekleri Kanunu) ve buna bağlı olarak çıkarılacak yönetmelik kapsamında değerlendirilmek üzere, mensubu bulunduğunuz mesleğin tanımı, eğitim durumu, görev ve sorumlulukları ihtiva eden 
görüşleriniz değerlendirmeye alınacaktır" (13). Bu mektup sonucunda Podoloji Kanunu'nun ilk temelleri için resmi çalışmalar başlamıştır. 06/04/2011 tarihli 6225 sayılı kanunla podolog ve podolojinin kanunen tanımı yapılmıştır.

Yayımlanan kanuna göre, Türkiye'de podoloğun tanımı, Resmi Gazete'den alınan haliyle şu şekildedir: "Podolog; meslek yüksekokullarının Podoloji programından mezun; bireylerin ayak sağlığının korunması ve bakımına yönelik hizmet veren ve ilgili uzman tabibin teşhisine ve tedavi için yönlendirmesine bağlı olarak hastaların ayak tedavisini yapan sağlık teknikeridir"(14). Aynı kanunun ilgili maddesinde "diploması veya meslek belgesi olmadan bu maddede tanımlanan meslek mensuplarının yetkisinde olan bir işi yapan veya bu unvanı takınanlar bir yıldan üç yıla kadar hapis ve ikiyüz günden beşyüz güne kadar adli para cezası ile cezalandırılır" da denilmiş(14), podoloji mesleği kanunen koruma altına alınmıştır. Bu yasa, 26 Nisan 2011 tarihinde yayınlanarak yürürlülüğe girmiştir.

Ülkemizde podologluk, eğitimi verilmeden yasada tanımlanan ilk sağlık mesleğidir. 15 Haziran 2011 tarihinde T.C. Sağlık Bakanlığı Sağlık Eğitimi Genel Müdürlüğü “podolog" mesleğinin çalışma şartları ile iş ve görev tanımlarını belirlemek üzere yaptığı toplantıya davet mektubuyla Podoloji Derneği Başkanını komisyonda görev yapmak üzere davet etmiştir.

22 Mayıs 2014 tarihli ve 29007 sayılı Resmi Gazete'de podoloğun iş ve işlemlerini tanımlayan yönetmelik yayımlanmıştır. Buna göre, podolog;

a) ayak sağlığı ve korunmasına yönelik farkındalık geliştirilmesi çalışmalarında görev alır,

b) sağlıklı bireylerde; medikal ayak bakımı yapar ve bu konuda eğitim verir,

c) ilgili uzman tabibin teşhisine ve tedavi için yönlendirmesine bağlı olarak; tırnak protez uygulamaları, bandaj, sargı, parmak yastıkları ve ayak destekleri uygulamalarını yapar, ayak sağlığı sorunlarını, tırnak patolojilerinin ve nasırların değerlendirilmesi önlenmesi ve tedavisinde görev alır (15).

\section{Podologların çalışma alanı}

Podoloğun çalışma alanı, temelde ayağın dermatolojik ve ortopedik kısmi müdahalelerini içermektedir. Meslek, hekimlik alanına ait olmamakla birlikte, kendi başına yöntemsel olarak tedavi edici ve bağımsız çalışmayı kapsamaktadır. Podolog, Grünewald'e göre, "temel olarak, doktorun müdahale alanını destekleyici ve tamamlayıcı yönde çalışmaktadır" (3).
Podoloğun görevi, ayağın sağlıklı kalmasını sağlayan koruma yöntemlerini uygulamak, ağrılı ya da deformasyona uğramış ayağı da tedavi etmektir. Bu sadece deri ve tırnak alanındaki patolojileri değil, ayağın duruş bozukluklarını ve ayakta oluşan yürüyüş bozukluklarını da içermektedir. Dolayısıyla, podologlar, normalden farklıyürüyüş şekli bulunan hastadaki duruş ya da bası bozukluğunu tespit ettikten sonra, altta yatan, konjenital ya da sekonder nedenleri belirleyerek tedavi planını uygular. Normalden farklı yürüyüş bozukluğunun nedeni, kişide bazen ağrılı clavis (corn) ya da kronik ağrılı unguis incarnatus olabilir. Bu rahatsızlıklar halk arasında, sırasıyla nasır ve tırnak batması olarak bilinmektedir. Kişi, ağrıyan yere teması azaltmak için farklı bir bası şekli ya da parmak kontraksyonu geliştirmiş olabilir. Dolayısıyla ağrıyı hafifletmek için geliştirilen anormal basış şekillerinin eklemlerde ve ayakta oluşturduğu basınç düzeltilmelidir. Tedavi planında öncelik, patolojik bulgunun, yani clavis'in ya da unguis incarnatus'un ortadan tedavi edilmesine yöneliktir. Bunun için basınç azaltıcı destekler, ortozlar, tabanlık ya da Fransızca'da orthonyxie denilen tırnak batmasının özel aparatlarla tedavisi gibi yöntemler kullanılabilir. Bu uygulamalarla podoloğun tedavi etmesi gereken cilt veya tırnak patolojisi değişiklikleri azaltııı, hatta yok edilebilir. Podolog, hastanın tedavisini gerçekleştirirken çok çeşitli freze uçları olan mikro motor ekipmanları, hekim tarafından reçete edilmiş ilaç ve fiziksel tedavi yöntemleri kullanır(3).

Birinci basamak tedavi hizmetlerinde yer alan podoloji/ podolog, koruyucu, önleyici ve tedavi edici olmak üzere üç aşamalı bir sağlık hizmetidir (16). Bu üç aşama, birincil, ikincil ve üçüncül koruma aşamaları olarak ele alınabilir $(17,3)$. Birincil koruma açısından podolojinin işlevi, ayağın sağlıklı halinin korunmasını sağlamaktır. Ayakta, cilt, tırnak ve eklemde oluşacak hastalıkları engellemek için verilen hizmetleri kapsar. Bunlar içerisinde, kişi için uygun ayakkabıyı anlatmak, çorap seçimi ve kullanımını tarif etmek, öz bakımı ve doğru tırnak kesimini açıklamak yer almaktadır.

İkincil korumanın kapsamında ise ayakta oluşan eklem deformasyonunun, ciltte oluşan değişikliklerin, tırnaktaki yapısal ve şekilsel bozulmaların önceden tanımlanması bulunmaktadır. Burada podolog, düzenli ayak muayenelerini, kompleks ayak bakımlarını gerçekleştirir ve tırnakta oluşan değişimleri ortadan kaldırmak ya da eklem deformasyonunun var olduğu durumlarda, ciltte oluşması muhtemel problemleri gidermek amacıyla özel ortoz, ayakkabı modifikasyonu, ayak egzersizleri gibi metotlar kullanır. Çoğu kez, ayakta uyuşma ya da karıncalanma gibi şikayetlerle podoloğa başvuran kişi, yapılan incelemeler sonucunda ve podoloğun ilgili hekime yönlendirmesiyle, aslında diyabet hastası olduğunu öğrenmektedir. Bu noktada, podoloğun hekime destek unsuru olarak çalışması önemlidir. 
Üçüncül korumada, travmaya bağlı problemlere yönelik tedaviyi, yanlış uygulamaların ya da sistemik hastalıkların sonucunda ayakta oluşan hasarlar sonucu yapılan uygulamalar bulunmaktadır. Burada amaç, ayakta oluşan hasarın olumsuz sonuçlarının sınırlandırılmasıdır. Örneğin, charco ayağı gelişmiş bir diyabet hastasının ayağındaki callus ve corn oluşumlarını gidermeye yönelik çalışmalar, bu gruba girmektedir. Podologlar, bu noktada uyguladıkları tedavilerle, medikal tedaviye destek vermekte, hekim ile sıkı işbirliği içerisinde çalışmaktadırlar. Bunun sonucunda, hastanın yaşama uyum göstermesi, sorunuyla başetmesi sağlanmakta, mevcut durumun üzerine eklenecek yeni olası problemlerin ortadan kaldırılması hedeflenmektedir.

\section{Sağlık hizmet sunumunda podologların önemi}

Her yaştaki insan için ayaklarda oluşan problem yaşam kalitesini olumsuz yönde etkiler. Yaşam kalitesinin bozulması, kişinin psikolojik olarak da olumsuz etki altında kalmasına neden olacaktır. Yürüme eylemini gerçekleştirirken ayağında ağrı hisseden bir insan, çoğu zaman daha az yürür, sağlıklı yaşam ve hastalıklardan korunma için önerilen fiziksel aktiviteleri yerine getirmekte zorlanır. Bu durumdan bilhassa yaşlı ve bakıma muhtaç olan insanlar daha fazla etkilenmektedir. Bir başka deyişle, "yaşam alanı ve işlevsellik büyük ölçüde sınırlanır, yetersizlik duygusu gelişir, günlük yaşam etkinliklerini gerçekleştirme yeteneği azalır ve birey sosyal çevreden uzaklaşır" (18).

Dünya Sağlık Örgütü tarafından sağlık; sadece hastalık ve sakatlığın olmaması değil, bedensel, ruhsal ve sosyal açıdan tam bir iyilik hali olarak tanımlanmaktadır (19). Insanları hastalıklardan korumak, hastalıklarını tedavi etmek, tedavi alan kimsenin tekrar hastalanmasını önlemek için yapılan faaliyetler, "sağlık hizmetleri" olarak adlandırılmaktadır. Sağlıkta insan gücü ise sağlık hizmeti sunumunda en önemli unsurlardan biridir ve sağlık hizmeti üreten herkesi kapsamaktadır. Günümüzde çok çeşitli branşlardan oluşan bir ekip hizmeti olarak verilen sağlık hizmetleri sunumunda verimlilik önem kazanmaya başlanmıştır. Etkili bir sağlık hizmeti sunmak için eğitim görmüş olan sağlık çalışanları, tarihin her döneminde yapılan işin temel unsuru ve belirleyicisi olmuştur (19).

T.C. Sağlık Bakanlığı da ülkemizde ihtiyaç duyulan podologların eksikliği giderilmesi gereken önemli bir meslek grubu olduğunu belirlemiş ve eğitim programlarının oluşturularak yetiştirilmesi için önemli çalışmalar gerçekleştirmiştir.

\section{Türkiye'de podoloji eğitimi veren üniversiteler}

Podologların akademik eğitimi ile ilgili ilk çalışma 16 Kasım 2011 tarihinde Kocaeli Üniversitesi Umuttepe
Yerleşkesi'nde başlamış, burada meslek öncüleri ile podologluk eğitim çalıştayı yapıımıştır. Yapılan bu çalıştayda özellikle diyabet hastalarının tedavi ekibinde yer alan podologların önemine vurgu yapılmış ve üniversitede eğitiminin başlamasına karar verilmiştir (20).

2013-2014 eğitim öğretim yılında Kocaeli Sağlık Hizmetleri Meslek Yüksekokulu Podoloji Programına ÖSYM tarafından ilk defa MYP ile öğrenci yerleştirilmesi yapılmıştır (21). Bunu takiben, 2014-2015 akademik yılından itibaren Acıbadem Üniversitesi Sağlık Hizmetleri Meslek Yüksekokulu Podoloji Programı ve Biruni Üniversitesi Meslek Yüksekokulu Podoloji Programı öğrenci kabul etmeye başlamışlardır. 2016-2017 akademik yılında, bu iki üniversiteyi Harran Üniversitesi Şanlıurfa Sağlık Hizmetleri M.Y.O. Podoloji Programı takip etmiştir. Ayrıca Harran Üniversitesi, Türkiye'nin ilk podoloji sempozyumuna da ev sahipliği yapan üniversite olmuştur. Acıbadem Mehmet Ali Aydınlar Üniversitesi de ilk Uluslararası katılımlı Podoloji Kongresi'ni düzenleyen üniversitesidir. En yakın tarihli olarak, Bülent Ecevit Üniversitesi Ahmet Erdoğan Sağlık Hizmetleri M.Y.O. Podoloji Programı da, 2017-2018 akademik yılından itibaren öğrenci kabul etmektedir $(22,23,24,25)$. Aşağıda yer alan Tablo 1 ve Tablo 2'de 2017-2018 ÖSYM Tercih Kılavuzu'na göre üniversitelerdeki podoloji programları ve kontenjanları görülmektedir.

Tablo 1. 2017-2018 ÖSYM tercih kllavuzuna göre vakıf üniversitelerinin podoloji programı kontenjanları

\begin{tabular}{lcccc}
$\begin{array}{l}\text { Üniversite } \\
\text { (Devlet-Vakıf) }\end{array}$ & $\begin{array}{c}\text { Puan } \\
\text { Türü }\end{array}$ & $\begin{array}{c}\text { 1. Öğretim } \\
\text { Kontenjan }\end{array}$ & $\begin{array}{l}\text { 2.0̈ğretim } \\
\text { Kontenjan }\end{array}$ & $\begin{array}{c}\text { OK. Bir. } \\
\text { Kontenjan }\end{array}$ \\
\hline $\begin{array}{l}\text { Devlet Üniversitesi } \\
\text { (3 Adet) }\end{array}$ & YGS-2 & 125 & --- & 4 \\
$\begin{array}{l}\text { Vakıf Üniversitesi } \\
\text { (2 Adet) }\end{array}$ & YGS-2 & 55 & 25 & -- \\
Toplam Kontenjan & 209 & 180 & 25 & 4
\end{tabular}

Tablo 2. 2017-2018 ÖSYM tercih kllavuzuna göre vakıf üniversitelerinin podoloji programı kontenjanları

\begin{tabular}{|c|c|c|c|c|c|c|}
\hline Üniversite Ismi & il & $\begin{array}{l}\text { Puan } \\
\text { Türü }\end{array}$ & $\begin{array}{l}\text { \%100 } \\
\text { Burslu }\end{array}$ & $\begin{array}{c}\% 50 \\
\text { Burs/u }\end{array}$ & $\begin{array}{c}\% 25 \\
\text { Burs/u }\end{array}$ & Ücretli \\
\hline $\begin{array}{l}\text { Acıbadem } \\
\text { Mehmet Ali Aydınlar } \\
\text { Üniversitesi }\end{array}$ & İstanbul & YGS-2 & 6 & 44 & --- & --- \\
\hline Biruni Üniversitesi & İstanbul & YGS-2 & 3 & --- & 27 & --- \\
\hline Toplam Kontenjan & 80 & & 9 & 44 & 27 & \\
\hline
\end{tabular}




\section{Sonuç ve öneriler}

Tıbbi açıdan ele alındığında, ayak sağlığı ve bakımının önemi elbette yadsınamaz. Angın'a göre, "hem üzerinde yürünen zemine uyum sağlaması bakımından fleksibil, hem de yük taşıyabilmesi için rijit yapıya sahip olan ayak, insan vücudunun doğrudan yer ile temasını sağlayan tek organdır. Hemen bütün aktiviteler için uygun postür, ayaklar üzerinde sağlanırken, bu aktivitelerde gereken stabilizasyon da kısmen ayak/ayakkabı ve yer arasındaki sürtünme ile elde edilmektedir. Çevre ile doğrudan temas halinde olan ayağın üzerine etkili olan farklı yön ve büyüklüklerdeki eksternal kuvvetlere bağlı olarak, sıklıkla fonksiyonel bozukluklar ve deformiteler gelişmekte, 21 yaş ve üzeri kişilerin yaklaşık \%80'inde en az bir ayak problemi olduğu ileri sürülmektedir" (26). Bu kadar ciddi oranda ayak problemlerinden muzdarip bireylerin varlığı bize aslında podolojinin ne kadar büyük bir gereksinim olduğunu ve önemini göstermektedir. Diğer yandan, podolojinin sıklıkla karıştırıldığı podiatri de ülkemizde yeterince bilinmemekte ve zaman zaman iki terimin birbirinin yerine kullanıldığı görülmektedir. Yine de podolojiye kıyasla, tıp bilimleri içerisinde bir yeri olan podiatri, podolojiden daha fazla kabul görmektedir. Yürütülen akademik çalışmalara bakıldığında, podiatrinin daha fazla bilinirliğe sahip olduğu söylenebilir. Angın'ın da belirttiği üzere, "normal ayak ve ayak problemlerine yaklaşımda öne çıkan bilim dallarından biri olan podiatri, batılı ülkelerin birçoğunda üniversite düzeyinde lisans eğitimi olarak verilmekte, literatürde bu alanda çok değerli klinik ve laboratuar çalışmaları bulunmaktadır" (26). Bu noktada, benzeri eğitimlerin, gerek lisans ve yüksek lisans, gerek ön lisans, gerekse

\section{Kaynaklar}

1. Medical Dictionary. (Farlex Partner Medical Dictionary @ Farlex 2012) https://medical-dictionary.thefreedictionary.com/podology. Erişim tarihi: 15.02.2018.

2. Bilir, N. "Yaşlanan Toplum." Yaşlılıkta Kaliteli Yaşam. Hacettepe Üniversitesi Geriatrik Bilimler Araştırma ve Uygulama Merkezi. http://www.gebam.hacettepe.edu.tr/yaslilikta_kaliteli_yasam_son. pdf . Erişim tarihi: 07.03.2018.

3. Grünewald, K. Theorie der medizinischen Fußbehandlung. München: Neuer Merkur, 2002:15-96

4. Brouwer, A. Die Dorfbaderstube. http://www.bildergipfel.at/artist/ adriaen_brouwer/page,2. Erişim tarihi: 25.02.2018

5. Teniers d.J., D. Die Baderstube. http://www.lot-art.com/auction-lots/ David-Teniers-d-J-1610-Antwerpen-1690-Brussel-Umkreis/2981david_tenier-08.12-hampel. Erişim tarihi: 25.02.2018.

6. Dagnall, J.C., "A History of Chiropody-Podiatry and Foot Care." Br J Chiropody. 1983;48:137-83.

7. Levy, L.A. "Podiatric Medicine: The Evolution of Practice and Formal Education." Principles and Practice of Podiatric Medicine. New York: Churchill Livingstone, 1990. mesleki eğitim seviyelerinde aslında podoloji alanında da verildiğini, bundan daha da önemlisi FIP-IFP'nin, aslında hem podologları hem de podiatristleri bir araya getirdiğini belirtmek yerinde olacaktır. Bu noktaların atlanması ya da gözden kaçırııması, maalesef aslında ayak sağlığını ilgilendiren çalışma dallarından birinin yok sayılması anlamına gelmektedir.

Oysa, podologların yetiştirilmesi ve tanınması, başta diyabetik ayak olmak üzere, konjenital ya da travmaya bağlı gelişen ayak problemleri ile ilgili her türlü bakım ve tedavide hem tıp dünyasının omuzlarındaki yükü hafifletecek, hem yeni iş kolları oluşturarak istihdam sağlayacak, hem de hijyenik olmayan ve sağlıksız koşullarda ayak bakımı adı altında gerçekleştirilen uygulamaların önünü keserek toplumsal bilinçlenme sağlayacaktır. Türkiye'de yalnızca beş üniversitede verilen ön lisans programları ile podoloji eğitimleri sağlanmakta, ancak mezunların henüz kamu kurumlarına atanması söz konusu değilken, öğretim kadroların da uzman podologların istihdamı konusunda sıkıntı yaşandığı gözlemlenmektedir. Diğer yandan, ülkemize kıyasla, podologlar tüm dünyada bağımsız çalışan mesleklerden biri olarak kabul görmektedir. Pek çok ülkede podologlar hekime destek olarak, kendi kliniklerinde çalışmaktadırlar. Ülkemizde de benzeri mevzuat düzenlemeleriyle mezun podologların istihdamının geliştirilmesi gerekmektedir. Yine bir başka düzenlemenin de eğitim alanında yapılması ve akademik anlamda podoloji eğitimin geliştirilebilmesi için alanda uzman podologların eğitim kadrolarında yer alması önemli bir adım olarak değerlendirilmektedir.

8. Klenerman, L. "Editorial: Podiatry." The Journal of Bone and Joint Surgery. 1991;73-B: 1-2.

9. Fédération Internationale Des Podologues. http://www.fip-ifp.org/. Erişim tarihi: 04.02.2018.

10. Verband Deutscher Podologen. http://www.verband-deutscherpodologen.de/ausbildung-zum-podologen/ Erişim tarihi: 04.02.2018.

11. Universitat de València, Degree of Podiatry. https:// www.uv.es/uvweb/college/en/undergraduate-studies/ undergraduate-studies-/degree-programmes-offered/degreepodiatry-1285846094474/Titulacio.html?id=1285847387142. Erişim tarihi: 04.03.2018.

12. Ivanova, T., Marite, S., Rudite, A. "Podology Educatıon in Latvia and European Union: A Comparative Study." Humanities and Social Sciences: Latvia. 2014; 22.2: 79-97.

13. Çoban, D. Derya Çoban. http://www.deryacoban.com.tr. Erişim tarihi: 12.02.2018.

14. Resmi Gazete. http://www.resmigazete.gov.tr/ eskiler/2011/04/20110426-1.htm Erişim Tarihi: 10.02.2018.

15. Resmi Gazete. http://www.resmigazete.gov.tr/ eskiler/2014/05/20140522.pdf. Erişim tarihi: 11.02.2018. 
16. Öztaş, D. "Sağlıklı Hayat Merkezleri." Sunum. Toplum Sağlığı Hizmetleri ve Eğitim Dairesi Başkanlığı. 2017. http://www. ulusalhemsirelikkongresi2017.org/sunum_fotograflar/Dilek_oztas-. pdf. Erişim tarihi: 07.03.2018.

17. Piyal, B. Sağlığı Koruma ve Geliştirme Illkeleri. Ankara Üniversitesi Uzaktan Eğitim Merkezi (ANKUZEM), Tıbbi Dokümantasyon ve Sekreterlik Programı Halk Sağlığı Dersi Kitabı, 2011; 92: 31-5.

18. Cumming, R.G., Salkeld, G., Thomas, M., Szonyi, G. "Prospective Study of The Impact of Fear of Falling on Activities of Daily Living, SF 36 Scores, and Nursing Home Admission." Journal of Gerontology: Medical Sciences. 2000; 55A.5: 299-305.

19. Bektaş, G. Sağlık İnsan Gücü Planlaması. İstanbul, Nobel Tıp Kitapevi, 2002:22-3.

20. Kocaeli Üniversitesi Podoloji Eğitimi Çalıştay Raporu. http://www. kocaeli.edu.tr/gecici/podoloji-egitimi-calistay-raporu.pdf. Erişim tarihi: 04.02.2018.

21. Kocaeli Üniversitesi Sağlık Hizmetleri MYO. http://kshmyo.kocaeli. edu.tr/wp-content/uploads/2014/07/Podoloji_-Prog-Hk-SSS-SHAP-12.4.2014.pdf Erişim tarihi 04.02.2018..
22. AcıbademÜniversitesi,SağlıkHizmetleriMeslekYüksekokulu,Podoloji Programı. https://dokuman.osym.gov.tr/pdfdokuman/2014/OSYS/ Tercih/2014-OSYSKONTKILAVUZU14072014.pdf. Erişim tarihi 04.02.2018.

23. Biruni Üniversitesi, Meslek Yüksekokulu, Podoloji Programı. https://dokuman.osym.gov.tr/pdfdokuman/2014/OSYS/ Tercih/2014-OSYSKONTKILAVUZU14072014.pdf. Erişim tarihi 04.02.2018.

24. Harran Üniversitesi Şanlıurfa Sağlık Hizmetleri MYO, Podoloji Programı. https://dokuman.osym.gov.tr/pdfdokuman/2016/ OSYS/2016-OSYSKontenKilavuzu28062016y.pdf. Erişim tarihi: 04.02.2018.

25. Bülent Ecevit Üniversitesi Ahmet Erdoğan Sağlık Hizmetleri MYO, Podoloji Programı. https://dokuman.osym.gov.tr/ pdfdokuman/2017/OSYS/LYS/KONTENJANKILAVUZ18072017.pdf. Erişim tarihi: 04.02.2018.

26. Angın, S. "Sayı Editöründen." Türkiye Klinikleri: Journal of Physiotherapy and Rehabilitation-Special Topics. 2016; 2: 1. 